\title{
Efek ekstrak etanol kedelai hitam (Glycine soja) terhadap ketebalan dermis mencit (Mus musculus L.) pasca unilateral ovariektomi
}

\author{
Effects of black soybean (Glycine soja) ethanol extract on dermis thickness of mice \\ (Mus musculus L.) after unilateral ovariectomy \\ Isna Kurotul Akyun, Susantin Fajariyah, Mahriani* \\ Jurusan Biologi, Fakultas Matematika dan Ilmu Pengetahuan Alam, Universitas Jember (UNEJ) \\ Jl. Kalimantan No.37, Krajan Timur, Sumbersari, Kec. Sumbersari, Kabupaten Jember, Jawa Timur 68121 \\ E-mail: mahriani.fmipa@unej.ac.id
}

Diterima 14 Oktober 2019 ; Disetujui 27 Desember 2019

\section{INTISARI}

Estrogen adalah hormon steroid yang diproduksi oleh ovarium. Salah satu fungsi estrogen dalam tubuh adalah memicu sintesis kolagen oleh fibroblas. Kandungan kolagen berperan terhadap ketebalan dermis. Defisiensi estrogen dapat menyebabkan terganggunya sintesis kolagen, sehingga berdampak pada penurunan ketebalan dermis. Ovariektomi unilateral merupakan tindakan pengangkatan satu ovarium yang menggambarkan kondisi defisiensi estrogen. Defisiensi estrogen dapat diatasi dengan pemberian fitoestrogen. Salah satu sumber fitoestrogen yaitu biji kedelai hitam. Tujuan dari penelitian ini adalah untuk mengetahui pengaruh ekstrak kedelai hitam terhadap ketebalan dermis mencit (Mus musculus L.) pasca ovariektomi. Dosis ekstrak etanol kedelai hitam yang digunakan yaitu $0,31 \mathrm{~g} / \mathrm{ml} / \mathrm{hari}$ dan $0,63 \mathrm{~g} / \mathrm{ml} / \mathrm{hari}$, diberikan secara oral (gavage) selama 20 hari. Hasil penelitian menunjukkan dosis $0,31 \mathrm{~g} / \mathrm{ml} /$ hari dan 0,63 $\mathrm{g} / \mathrm{ml} /$ hari dapat meningkatkan ketebalan dermis mencit.

Kata kunci: kedelai hitam, ketebalan dermis, ovariektomi

\begin{abstract}
Estrogen is a steroid hormone produced by the ovaries. Estrogen is a hormone that triggers collagen synthesis by fibroblast.Collagen has affects for thickness of dermis.Estrogen deficiency can lead disruption collagen synthesis, so has an impact on decline dermis thickness. Unilateral ovariectomy is the act of removal of one ovary in the female reproductive system and is a model for estrogen deficiency. The condition of estrogen deficiency can be overcome by giving phytoestrogens. Black soybean seed is one of phytoestrogens source. The purpose of this study was to determine the effect of black soybean extract after ovariectomy on increasing on dermis thickness (Mus musculus L.). The dosage of black soybean ethanol extract used was $0.31 \mathrm{~g} / \mathrm{ml} /$ day and $0.63 \mathrm{~g} / \mathrm{ml} /$ day administered orally (gavage) for 20 days. The results showed a dose of $0.31 \mathrm{~g} / \mathrm{ml} /$ day may and $0.63 \mathrm{~g} / \mathrm{ml} /$ day increase dermis thickness of mice.
\end{abstract}

Keywords: black soybean, dermis thickness, ovariectomy 


\section{PENDAHULUAN}

Ovariektomi merupakan tindakan pengambilan ovarium yang dapat dibedakan menjadi dua, yaitu unilateral ovariektomi (pengambilan satu ovarium) dan bilateral ovariektomi (pengambilan 2 ovarium). Ovariektomi dapat menyebabkan penurunan kadar estrogen (Cassidy et al., 2006). Penurunan kadar estrogen menyebabkan terganggunya sintesis kolagen oleh fibroblas dalam dermis, sehingga akan mempengaruhi ketebalan dermis (Son et al., 2005).

Lapisan dermis merupakan lapisan yang paling tebal pada kulit. Dermis mengandung jaringan ikat yang terdiri atas serat elastin dan kolagen (Akbar, 2007). Dermis tersusun atas $85-90 \%$ serat kolagen (Castelo-Branco et al., 1993). Kandungan kolagen berperan terhadap ketebalan kulit (Markova et al., 2004). Kolagen akan membentuk ikatan antar sel fibroblas dan menyebabkan ketebalan dermis. Kandungan kolagen yang rendah dapat mengakibatkan struktur kulit kendur dan tipis sehingga menyebabkan rentan terhadap luka, selain itu rendahnya kandungan kolagen juga menyebabkan terhambatnya penyembuhan luka (Junquiera et al., 2007).

Ketebalan dermis dipengaruhi oleh hormon estrogen. Estrogen akan berikatan dengan reseptor $\beta$-estrogen pada fibroblas (Kavitha dan Thampan, 2008). Ikatan estrogen dengan reseptor dapat memicu sel fibroblas dermis untuk mensekresikan molekul prokolagen membentuk kolagen (Junqueira et al., 2007; Irrera et al., 2017). Menurut Kavitha dan Thampan (2008) defisiensi estrogen dapat menurunkan densitas kolagen. Kandungan kolagen yang rendah merupakan indikasi dari menurunnya ketebalan kulit (Rainee-Fenning et al., 2003). Estrogen juga dapat mengurangi aktivitas enzim metalloproteinase (MMP) yang berfungsi dalam mendegradasi kolagen (Baumann dan Saghari, 2009).

Defisiensi estrogen dapat diatasi dengan pemberian fitoestrogen (Primiani, 2013). Fitoesterogen merupakan metabolit sekunder dari tumbuhan yang berperan sebagai estrogen eksogen alami (Glover dan Assinder, 2006). Fitoestrogen antara lain isoflavon, lignin, dan coumestan (Jefferson et al., 2002). Isoflavon merupakan fitoestrogen yang memiliki kemampuan estrogenik paling kuat (Biben, 2012).

Salah satu tumbuhan yang mengandung fitoestrogen adalah kedelai hitam (Glycin soja). Kedelai hitam merupakan sumber fitoestrogen dari kelompok Leguminoceae yang memiliki kandungan isoflavon tertinggi (Sulistiani et al., 2014). Kedelai hitam mengandung senyawa isoflavon yang terdiri atas genestein $56,9 \%$, daidzein $40,5 \%$, dan glicetin 2,6\% (Fawwaz et al., 2016). Genestein mempunyai afinitas tinggi untuk berikatan dengan reseptor $\beta$ estrogen, sehingga akan menginisiasi sintesis kolagen dan mengurangi aktivitas MMP pada kulit (Thornton, 2013; Baumann dan Saghari, 2009). Oleh karena itu, perlu dilakukan penelitian untuk mengetahui efek pemberian ekstrak kedelai hitam (Glycine soja) terhadap ketebalan kulit pada mencit (Mus musculus) pasca ovariektomi.

\section{MATERI DAN METODE}

\section{Materi}

Bahan yang digunakan dalam penelitian ini adalah mencit (Mus musculus L.) betina strain Balb/C yang diperoleh dari Pusvetma Surabaya umur 2 bulan, pakan pallet (BRl) produksi PT. Chareon Pokphand Indonesia Animal Feedmill Co. Ltd Jakarta, sekam padi, akuades, ketamine (PantexHolland B. V) 10\%, xyla (Pantex-Holland B. V), benang silk dan cat gut no.3, betadine (Povidone Iodine) 10\%, alkohol 70\% (Mediss), antibiotik (Levoflaxacin), cairan $\mathrm{NaCl} 0,9 \%$, parasetamol, kasa steril (One me), biji kedelai hitam dari Balai Penelitian Kacang-kacangan dan Umbi-umbian Malang, kertas saring, kain saring, tissue, gloves, kloroform, larutan fiksasi (formalin 10\%), alkohol bertingkat $80 \%, 85 \%, 90 \%, 95 \%$, alkohol absolut, ,xylol, parafin, perekat untuk proses mounting, dan pewarna Hematoxylin Eosin (Suntoro,1983).

\section{Metode}

\section{Persiapan Hewan Uji}

Hewan uji yang digunakan adalah mencit (Mus musculus L.) betina strain Balb/C umur 60 hari. Mus musculus dipelihara dengan pemberian pakan dan diberikan minum secara ad libitum. 


\section{Perlakuan Mencit Unilateral Ovariectomy}

Mencit dibius dengan ketamine $10 \%$ dan xyla dengan perbandingan 1:1 sebanyak 0,05 mL. Mencit diletakkan secara terlentang pada papan bedah dan dilakukan pembedahan pada daerah abdomen serta diinsisi pada Muculus oblikus abdominis eksternus dan Musculus oblikus abdominis internus. Salah satu ovarium dipotong. Proses penutupan dengan dijahit pada bagian $M$. oblikus abdominis internusdan $M$. oblikus abdominis eksternus menggunakan benang cat gut sedangkan kulit menggunakan benang silk. Perawatan luka dilakukan dengan pemberian antibiotik sebanyak 0,05 $\mathrm{ml}$ dan parasetamol selama 1 minggu (Strom et al., 2012).

\section{Pembuatan Ekstrak Kedelai Hitam}

Kedelai hitam ditimbang, kemudian dioven dalam suhu $40-45^{\circ} \mathrm{C}$ selama $2-3$ hari. Selanjutnya digrinder dan diayak, kemudian tepung kedelai hitam ditimbang dan dimaserasi dalam alkohol $70 \%$ dengan perbandingan 1:4 (200 g tepung kedelai hitam: $800 \mathrm{~mL}$ alkohol $70 \%$ ) dan dihomogenkan, selanjutnya dimaserasi selama $2 \mathrm{x}$ 24 jam. Supernatan disaring untuk mendapatkan filtratnya. Filtrat dimasukkan ke dalam rotary evaporator dengan suhu $90^{\circ} \mathrm{C}$ hingga diperoleh filtrat tanpa alkohol. Filtrat tanpa alkohol dipanaskan di waterbath selama \pm 8 jam untuk mendapatkan crude extract dalam bentuk pasta (Panizzi et al., 2002).

\section{Perlakuan Hewan Uji}

Pemberian ekstrak kedelai hitam dilakukan pada mencit ovariektomi yang dimulai pada bulan ke-5. Pemberian ekstrak kedelai hitam dilakukan selama 20 hari berturut-turut secara oral (gavage) pada mencit. Dosis yang digunakan sesuai dengan penelitian (Abdi, 2017) yaitu $0,31 \mathrm{~g} / \mathrm{mL} /$ hari dan $0,63 \mathrm{~g} / \mathrm{mL} /$ hari. Pemberian ekstrak kedelai hitam dengan cara mencampurkan takaran pasta dengan aquades $1 \mathrm{~mL}$ sesuai dosis yang ditentukan yaitu $0,31 \mathrm{~g} / \mathrm{mL} /$ hari dan $0,63 \mathrm{~g} / \mathrm{mL} /$ hari.

\section{Pembuatan Preparat Histologi Kulit}

Mencit dianestesi dengan kloroform dan diletakkan di atas papan bedah dengan posisi telentang, kemudian dilakukan pembedahan hewan uji. Tahap pertama pengambilan sampel kulit yaitu penghilangan rambut-rambut kulit bagian dorsal menggunakan silet. Selanjutnya dibuat sayatan pada kulit bagian dorsal punggung dengan ukuran $3 \times 3 \mathrm{~cm}$. Berdasarkan Dellman dan Brown (1992) kulit bagian dorsal temasuk kulit tipis yang memiliki ketebalan kulit lebih tinggi dibandingkan dengan kulit ventral. Pembuatan preparat histologi kulit dilakukan dengan metode parafin dengan pewarnaan Hematoxylin-Eosin (Suntoro,1983).

\section{Parameter Penelitian}

Pengukuran ketebalan lapisan dermis dilakukan menggunakan Optilab. Pengukuran dilakukan dalam 1 bidang pandang pada masing-masing sampel. Setiap bidang pandang dilakukan pengukuran pada 6 area ( 3 area lapisan tipis, 3 area lapisan tebal). Hasil perhitungan dari 6 area tersebut kemudian dirata-rata dan didapatkan nilai rata-rata ketebalan dermis (Oltulu et al., 2018).

\section{Analisis Data}

Data ketebalan dermis secara kuantitatif disajikan dalam bentuk (rata-rata) \pm standar deviasi. Hasil perhitungan ketebalan dermis dianalisis menggunakan aplikasi perangkat lunak Statistical Product and Service Solutions (SPSS) versi 15.0 Multiple Range Test (DMRT) untuk mengetahui menggunakan uji One Way ANOVA. Selanjutnya, dilakukan uji Duncan adanya beda nyata antar kelompok uji (Steel dan Torrie, 1993).

\section{HASIL}

Hasil perhitungan rata-rata ketebalan dermis mencit strain Balb/C berdasarkan uji One Way ANOVA diperoleh nilai signifikansi $\alpha=0,000<0,05$ yang menunjukkan bahwa pemberian ekstrak kedelai hitam berpengaruh nyata $(p<0.5)$ terhadap rata-rata ketebalan dermis (Tabel 1). Hasil rata-rata tersebut dapat dilihat pada Tabel 1.

Demikian juga hasil pengamatan penampang melintang struktur histologi lapisan dermis mencit menunjukkan bahwa setelah perlakuan ovariektomi 
mempunyai ketebalan dermis yang lebih tipis dan setelah pemberian ekstrak kedelai hitam menunjukkan ketebalan dermis yang lebih tebal, seperti pada Gambar 1.

Tabel 1. Rata-rata ketebalan dermis mencit strain Balb/C 5 bulan unilateral ovariektomi (ULO) pasca 20 hari pemberian ekstrak kedelai hitam

\begin{tabular}{cc}
\hline \multirow{2}{*}{ Perlakuan } & $\begin{array}{c}\text { Rata-rata Ketebalan Lapisan Dermis } \\
(\overline{\mathrm{x}} \pm \mathrm{SD}) \mu \mathrm{m}\end{array}$ \\
\hline $\mathrm{K}-$ & $564,53^{\mathrm{a}} \pm 10,78$ \\
\hline $\mathrm{K}+$ & $514,18^{\mathrm{b}} \pm 14,93$ \\
\hline $\mathrm{D} 1$ & $620,48^{\mathrm{c}} \pm 26,52$ \\
\hline $\mathrm{D} 2$ & $605,86^{\mathrm{c}} \pm 18,61$ \\
\hline
\end{tabular}

Angka yang diikuti superscript yang berbeda pada kolom yang sama menunjukkan perbedaan nyata antar perlakuan berdasarkan DMRT $(\alpha<0,05)$. K-: mencit tanpa ULO, K+: mencit ULO, D1: mencit ULO dosis 0,31 $\mathrm{g} / \mathrm{mL} / \mathrm{hari}, \mathrm{D} 2$ : mencit ULO dosis $0,63 \mathrm{~g} / \mathrm{mL} / \mathrm{hari}$.

\section{PEMBAHASAN}

Peningkatan rata-rata ketebalan dermis pada kontrol positif diakibatkan adanya tindakan ovariektomi. Ovariektomi menyebabkan penurunan kadar estrogen (Sutejo et al., 2016). Penurunan kadar estrogen memberikan dampak terhadap penurunan sintesis kolagen oleh fibroblast serta mengaktifkan enzim MMP sehingga mengakibatkan penurunan ketebalan dermis (Son et al., 2005; Baumann dan Saghari, 2009).

Ketebalan dermis merupakan hal yang harus dipertahankan. Lapisan dermis yang tebal mengandung banyak kolagen yang berfungsi mencegah menipisnya lapisan kulit yang ditandai dengan keriput, serta menjaga elastisitas kulit (Bradell dan Kenneth, 2008). Ketebalan dermis dapat ditentukan melalui densitas kolagen (RaineFenning et al., 2003). Kolagen disintesis oleh fibroblas (Kavitha dan Thampan, 2008; CasteloBranco et al., 1993). Kolagen akan membentuk ikatan antarsel fibroblas dalam dermis. Semakin banyak ikatan yang terbentuk dapat menyebabkan dermis menjadi tebal, sebaliknya ketika jumlah kolagen berkurang maka ikatan semakin merenggang sehingga menyebabkan dermis menjadi kendur dan tipis (Kavitha dan Thampan, 2008).

Sintesis kolagen oleh fibroblas dapat terjadi melalui pengaruh hormon estrogen (Kavitha dan Thampan, 2008). Terdapat reseptor $\alpha$-estrogen dan $\beta$-estrogen pada fibroblas. Fibroblas memiliki kadar reseptor $\beta$-estrogen yang lebih tinggi (Haczynski et al., 2002). Estrogen akan berikatan dengan reseptor $\beta$-estrogen yang akan menstimulus fibroblas untuk mensintesis prokolagen menjadi kolagen (Thornton, 2013). Hal tersebut didukung oleh Shu dan Maibach (2011) bahwa penambahan estrogen dapat meningkatkan densitas kolagen yang diikuti dengan meningkatnya ketebalan dermis. Defisiensi estrogen juga akan mengaktifkan enzim MMP yang berfungsi dalam mendegradasi kolagen, sehingga akan terjadi penurunan densitas kolagen yang berefek pada penurunan ketebalan lapisan dermis (Baumann dan Saghari, 2009). 


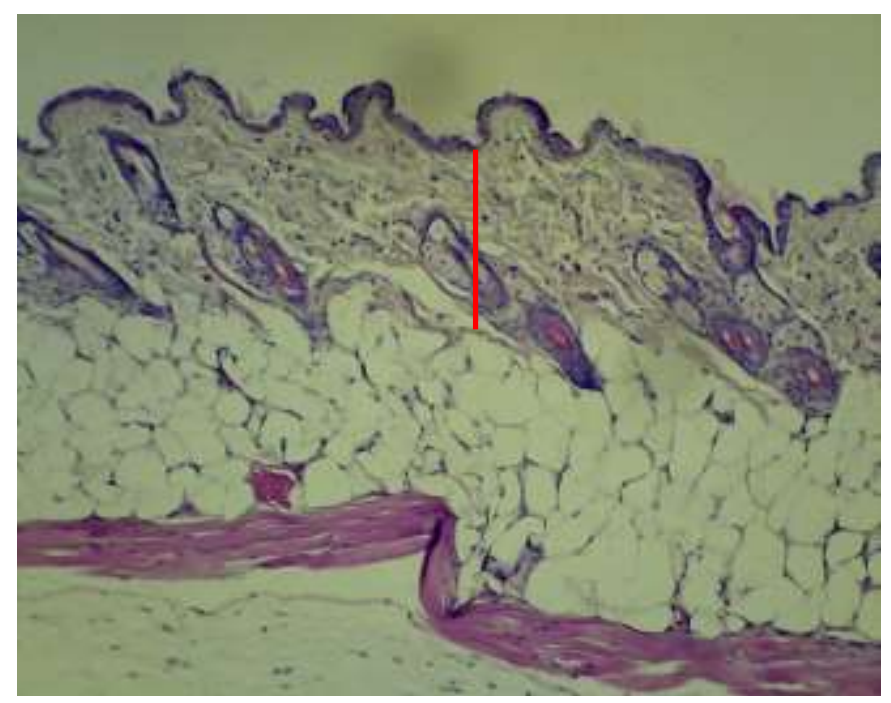

(a)

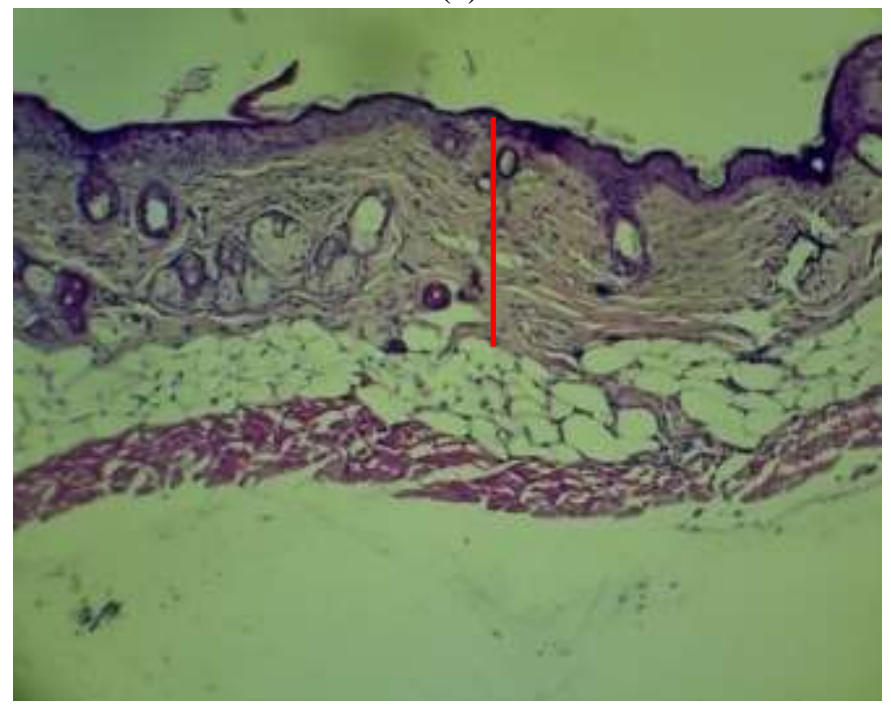

(c)

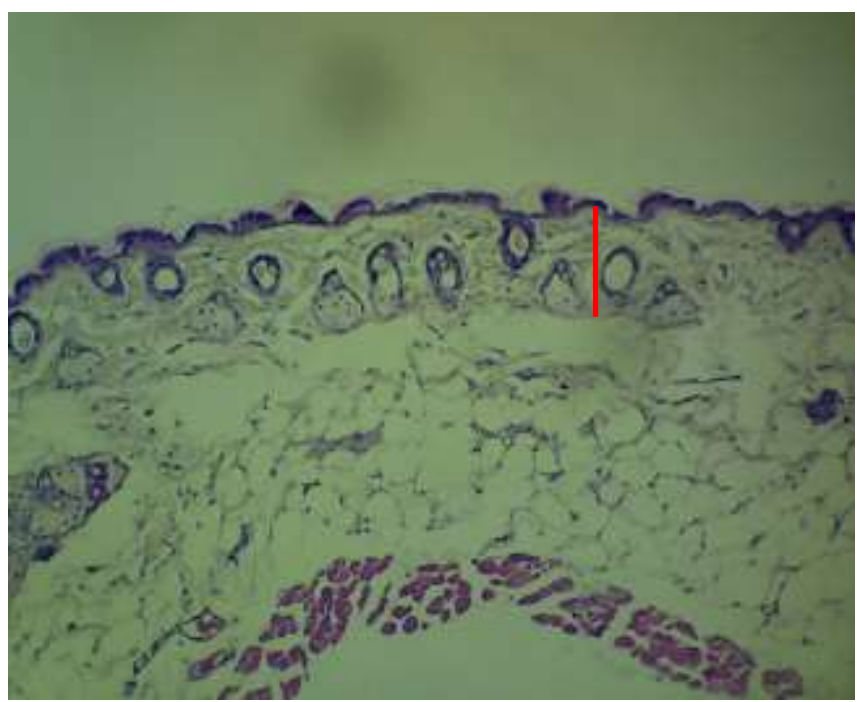

(b)

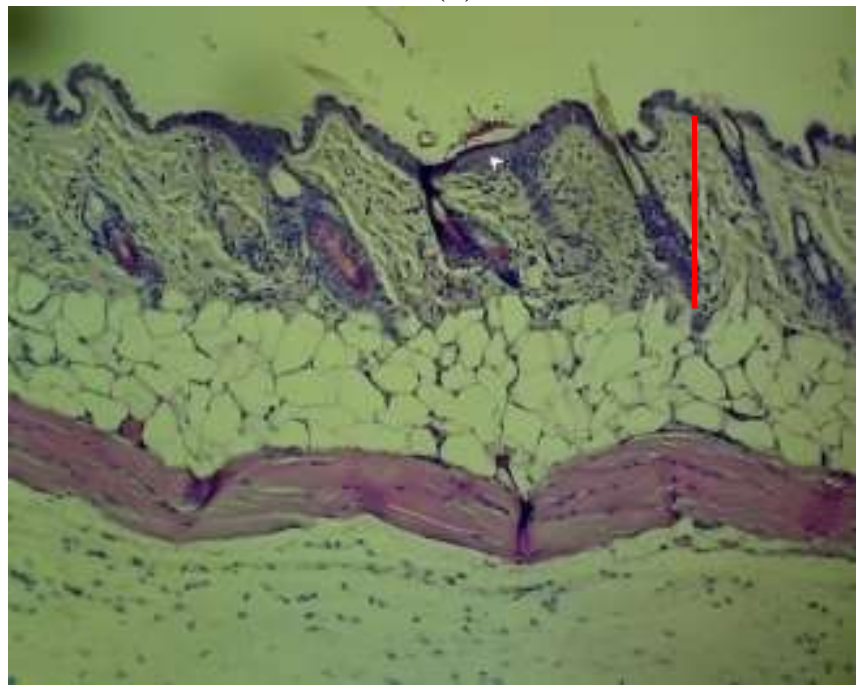

(d)

Gambar 1. Mikrograf penampang melintang dermis mencit (Mus musculus.L) unilateral ovariektomi dengan pewarnaan Hematoxylin Eosin (garis merah) (a) kontrol negatif; (b) kontrol positif; (c) dosis 1 (0,31 g/mL/hari); dan (d) dosis 2 $(0,63 \mathrm{~g} / \mathrm{mL} / \mathrm{hari})$

Pemberian ekstrak kedelai hitam dapat meningkatkan rata-rata ketebalan dermis. Perbedaan dosis $0,31 \mathrm{~g} / \mathrm{mL}$ dan $0,63 \mathrm{~g} / \mathrm{mL}$ menunjukkan pengaruh yang tidak berbeda terhadap peningkatan ketebalan dermis. Terbukti dari data (Tabel 1) bahwa ekstrak kedelai hitam merupakan sumber fitoestrogen yang dapat menggantikan estrogen yang hilang pada mencit ovariektomi serta mampu meningkatkan ketebalan dermis. Pemberian fitoestrogen dengan dosis rendah $0,31 \mathrm{~g} / \mathrm{mL}$ lebih efektif dibanding dengan dosis $0,63 \mathrm{~g} / \mathrm{mL}$ yang lebih tinggi, hal ini diduga karena dosis $0,31 \mathrm{~g} / \mathrm{mL}$ sudah optimal berikatan dengan reseptor estrogen.

Kedelai hitam mengandung genestein sebesar 56,9\% (Fawwaz et al., 2016). Senyawa genestein merupakan senyawa yang memiliki afinitas pengikatan tertinggi terhadap reseptor $\beta$-estrogen (Thornton, 2013). Melalui pengikatan dengan reseptor $\beta$-estrogen genestein dapat meningkatkan sintesis matriks ekstraseluler, deposisi kolagen, regenerasi epitel, dan proses lainnya yang terkait dengan perbaikan kulit pada tikus ovariektomi (Polito et al., 2012, Irrera et al., 2017). Menurut Uyar et al. (2014) bahwa pemberian ekstrak etanol kedelai (Glycine max L.) dengan dosis $100 \mathrm{mg} / \mathrm{kg}$ dan $200 \mathrm{mg} / \mathrm{kg}$ mampu meningkatkan densitas kolagen dan ketebalan dermis pada tikus.

Pemberian ekstrak kedelai hitam pada dosis 1 menunjukkan ketebalan dermis lebih tinggi, diduga bahwa konsentrasi hormon yang semakin tinggi 
akan mempengaruhi sel target dalam merespon hormon tersebut. Berdasarkan Cao et al. (2009) bahwa pemberian genestein pada dosis $50 \mu \mathrm{mol} / \mathrm{L}$ dan $100 \mu \mathrm{mol} / \mathrm{L}$ dapat menghambat aktivitas tyrosine kinase, sedangkan pada konsentrasi 25 $\mu \mathrm{mol} / \mathrm{L}$ tidak menghambat aktivitas tyrosine kinase. Tyrosine kinase berperan dalam sintesis kolagen. Sintesis kolagen oleh fibroblas dapat diregulasi melalui Transforming Growth Factor- $\beta$ (TGF- $\beta$ ) (Hidayat et al., 2013). Growth factor tersebut bekerja pada sel melalui jalur Tyrosine Protein Kinase signalling (TPKs). TGF- $\beta$ akan berikatan dengan tirosin kinase reseptor yang terdapat pada membran fibroblas dan mengaktifkan TPKs. Selanjutnya tirosin kinase akan mentransmisikan sinyal atau informasi ke inti untuk mengatur proliferasi dan diferensiasi sel. Penurunan aktivitas tyrosine kinase akan menghambat sintesis kolagen (Cao et al., 2009).

\section{SIMPULAN}

Pemberian ekstrak etanol kedelai hitam selama 20 hari meningkatkan ketebalan dermis mencit pasca unilateral ovariektomi. Pemberian ekstrak kedelai hitam pada dosis $0,31 \mathrm{~g} / \mathrm{mL} / \mathrm{hari}$ menunjukkan hasil ketebalan dermis yang tinggi dibandingkan dosis $0,63 \mathrm{~g} / \mathrm{mL} / \mathrm{hari}$. Fitoestrogen kedelai hitam terbukti dapat menggantikan estrogen endogen pasca dilakukan ovariektomi.

\section{SARAN}

Penelitian lanjutan sangat menarik untuk ditemukan dosis ekstrak kedelai hitam yang lebih rendah sehingga menemukan dosis optimum yang lebih tepat untuk memberikan efek positif meningkatkan ketebalan dermis.

\section{DAFTAR PUSTAKA}

Abdi, Y.F.R. 2017. Efek pemberian tepung kedelai hitam (Glycine soja) terhadap leukosit mencit (Mus musculus L.) implantasi pasca ovariektomi. Skripsi Jurusan Biologi FMIPA. Jember: Universitas Jember.
Baumann, L. dan L. Saghari. 2009. Cosmetic Dermatology Principles and Practice 2nd Ed. The McGraw-Hill Companies, Inc.

Biben, H.A. 2012. Fitoestrogen: Khasiat terhadap sistem reproduksi, non reproduksi dan keamanan penggunaannya. Seminar Ilmiah Nasional Estrogen sebagai Sumber Hormon Alami. Universitas Padjajaran.

Boulter, E., S. Estrach, A. Errante, C. Pons, L. Cailleteau, F. Tissot, G. Meneguzzi dan C.C. Feral. 2013. CD98hc (SLC3A2) regulation of skin homeostasis wanes with age. The Journal of Experimental Medicine 210(1): 173-190.

Bradell, L.A., and S.R. Kenneth. 2008. Skin structure and function: the body's primary defense against infection. Infectious Desease in Clinical Practice 16(2): 113-117.

Brown, G. dan T. Burns. 2005. Dermatologi Edisi Kedelapan. Jakarta: Erlangga.

Cao, C., S. Li, X. Dai, Y. Chen, Z. Feng, Y. Zhao dan J. Wu. 2009. Genestein inhibits proliferation and functions of hypertropic scar fibroblasts. Burns. 35: 85-97.

Cassidy, A., P. Albertazzi, L.I. Nielsen, W. Hall, G. Williamson, I. Tetens, S. Atkins, H. Cross, Y. Manios, A.Wolk, C. Steiner dan F. Branca. 2006. Critical Review of Health Effects of Soyabean Phyto-oestrogens in Post-menopausal Women. Proceedings of the Nutrition Society 65: 76-92.

Castelo-Branco, C., M. Duran, dan J. GonzalezMerlo. 1993. Skin collagen changes related to age and hormone replacement therapy. Obstet Gynecol Surv. 48:277-279.

Circosta, C., R.D. Pasquale, S. Samper dan F. Occhiuto. 2006. Effects of isoflavones from red clover (Trifolium pratense) on skin changes induced by ovariectomy in rats. Phytotherapy research 20: 1096-1099.

Comelekoglu, U., S. Yalin, E. Balli, dan M. Berkoz. 2012. Ovariectomy decreases biochemichanical quality of skin via oxidative stress in rat. Turk $\mathrm{J}$ Med Sci. 42(2):201-209. 
Dellmann H.D. dan E.M. Brown. 1992. Buku Teks Histologi Veteriner. Terjemahan oleh Hartono R, Penerjemah. Jakarta: UI.

Fawwaz, M., D.S. Muliadi dan A. Muflihunna. 2006. Kedelai hitam (Glycine soja) terhidrolisis sebagai sumber flavonoid total. Jurnal Fitofarmaka Indonesia 4(1): 194-198.

Flour, M. 2009. The Pathophysiology of Vulnerable Skin. World Wide Wounds Article.

Glover A. and S.J. Assinder. 2006. Acute exposure of adult male rats to dietary phytoestrogen reduces fecundity and alters epididymal steroid hormone receptor expression. Jour. Endoc. 189: 565-573.

Hacynski, J., R. Tarkowski, K. Jarzabek, M. Slomczynska, S. Wolczynski, D.A. Magoffin, J.A. Jarkowicki and A.J. Jakimiuk. 2002. Human cultured skin fibroblast express estrogen receptor $\alpha$ and $\beta$. International Journal of Molecular Medicine 10: 149-153.

Hidayat, T., M. Noer dan S. Rizaliyana. 2013. Peran topikal ekstrak gel Aloe vera pada penyembuhan luka bakar derajat dalam pada tikus. TOC 2(2): 26-30.

Irrera, N., P. Gabriele, R. D’Anna, M. Vacarro, V. Arcoraci, F. Squadrito, D. Altavilla and A. Bitto. 2017. Dietary management of skin health: the role of genistein. Nutrients 9(622): $1-10$.

Jefferson, W.N., E. Padilla-Banks, G. Clark and R.R. Newbold. 2002. Assessing estrogenic activity of phytochemicals using transcriptional activation and immature mouse uterotrophic responses. J Chrom. B Analytical Technologies in the Biomedical and Life Sci. 777(1-2):179189.

Junquiera, L.C., J. Carneiro dan R.O. Kelley. 2007. Histologi Dasar dan Atlas. Jakarta: EGC.

Kalangi, S.J. 2013. Histofisiologi Kulit. Manado: Fakultas Kedokteran Universitas Sam Ratulangi.
Kapusniak, V. 2006. Keratinization of Epidermal Cell. Medycyna Weterynaryjna Article 62(1): 11-15.

Kavitha, O. and R.V. Thampan. 2008. Factors influencing collagen biosynthesis. Journal of Cellular Biochemistry 104: 1150-1160.

Maibach, H. and G. Honari. 2014. Applied Dermatoxicology: First Edition. Academic Press.

Markova, M.S., J. Zeskand, B. McEntee, J. Rothstein, S. Jimenez and L.D. Siracusa. 2004. A role for the androgen receptor in collagen content of the skin. J Invest Dermatol. 123(6): 1052-1056.

Mas'ula, Y. dan A.S. Kusuma. 2018. Artikel Tinjauan: Aktivitas Antikanker Tanaman Rumput Lidah Ular (Hedyotis difussa Willd.). Farmaka. 15(3): 17-23.

Nanashima, N., K. Horie, H. Maeda, T. Tomisawa, M. Kitajima and T. Nakamura. 2018. Blackcurrant anthocyanins increase the levels of collagen, elastin, and hyaluronic acid in human skin fibroblasts and ovariectomized rats. Nutrients 10(495): 1-15.

Okat, Z. 2018. Molecular Dynamics of Estrogen Receptors. EJMO 2(4): 189-197.

Oltulu, P., B. Ince, N. Kokbudak, S. Findik and F. Kilinc. 2008. Measurement of epidermis, dermis, and total skin thickness from six different regions with a new ethical histometric technique. Turkish Journal of Plastic Surgery 26(2): 56-61.

Panizzi, M.C., S.P.G. Favoni, and A. Kikuchi. 2002. Extraction time for soybean isoflavone determination. Brazilian Archieves of Biology and Technology 45(4): 515-518.

Perzelova, V., F. Sabol, T. Vasilenko, M. Novotny, I. Kovac, M. Slezak, J. Durcak, M. Holly, M. Pilatova, P. Szabo, L. Varinska, Z. Criepokava, T. Kucera, H. Kaltner, S. Andre, H. Gabius, P. Mucaji, K. Smetana and P. Gal. 2016. Pharmalogical activation of estrogen receptor- $\alpha$ and $-\beta$ differentially modulates keratinocyte differentiation with functional impact on 
wound healing. International Journal of Molecular Medicine 37: 21-28.

Polito, F., H. Marini, A. Bitto, N. Irrera, M. Vaccaro and E.B. Adamo. 2012. Genistein aglycone, a soy-derived isoflavone, improves skin changes induced by ovariectomy in rats. $\mathrm{J}$ Pharmacol 165(4):994-1005.

Pradana, S. 2008. Prospek dan Manfaat Isoflavon sebagai Fitoestrogen Bagi Kesehatan. Jakarta: Balai Penerbit FKUI

Primiani, C.N. 2013. Potensi tepung tempe sebagai estrogen alami terhadap uterus mencit menopouse. Sains \& Matematika 1(2):47-51.

Raine-Fenning, N.J., M. P. Brincat, and Y. MuscatBaron. 2003. Skin aging and menopause: implications for treatment. Am J Clin Dermatol. 4(6): 371-378.

Sahay, R.K., A.K. Unnikrishnan, S.K. Bhadada and J.K. Agrawal. 2002. Hormone receptor disorders. Review Article JIACM 3(1): 65-80.

Sevrain, S., M. Yaar, J. Cantatore, A. Traish and A. Gilchrest. 2004. Estradiol induces proliferation of keratinocytes via receptor mediated mechanisms. The FASEB Jurnal: 1-24.

Shu, Y.Y. and H.I. Maibach. 2011. Estrogen and skin: ther-apeutic options. Am J Clin Dermatol. 12:297.

Sitasiwi, A.J. 2009. Efek paparan tepung kedelai dan tepung tempe sebagai sumber fitoestrogen terhadap jumlah kelenjar endometrium uterus mencit (Mus musculus L.). E-Journal UNDIP. 17(1): 1-10.

Son, E.D., J.Y. Lee, S. Lee, M.S. Kim, G.B. Lee, S. Chang, dan J.H. Chung. 2005. Topical application of 17b-estradiol increases extracellular matrix protein synthesis by stimulating tgf-b signaling in aged human skin in vivo. The Journal of Investigative Dermatology 124(6): 1149-1162.

Steel, R., dan Torrie J. 1993. Prinsip dan prosedur Statistik. Terjemahan dari Principles dan Procedure of Statistic . Jakarta: Gedia Pustaka.

Ström, O., J.A. Theodorsson, E. Ingberg, I.M. Isaksson and E. Theodorsson. 2012. Ovariectomy and $17 \beta$-estradiol replacement in rats and mice: A visual demonstration. Journal of Visualized Experiments 64: 1-4.

Suntoro, S.H. 1983. Metode Pewarnaan (Histologi dan Histokimia). Jakarta : Bhratara Karya Aksara.

Sutejo, I.R., H.D. Nurqistan, I. Rasyada, N.N. Yurriasih, A. Yunniar dan R. Ramadhani. 2016. Kandungan fitoestrogen ekstrak etanolik akar rami (Boehmeria nivea) menurunkan kadar kolesterol tikus yang diovariektomi. Nurse Line Journal 1(1): 83-89.

Thornton, M.J. 2013. Estrogens and Aging Skin. Dermato-Endocrinology 5(2): 264-273.

Thornton, M.J., A.H. Taylor, K. Mulligan, F. Alazzawi and C.C. Lyon. 2003. Oestrogen receptor beta is the predominant oestrogen receptor in human scalp skin. Experimental Dermatology 12: 181-190.

Uyar, B., O.N. Sivrikoz, U. Ozdemir, T. Dasbasi and H. Sacar. 2014. Histological investigation of the effect of soybean (Glycine max) extracts on the collagen layer and estrogen receptors in the skin of female rats. Clinics 69(12): 854861. 